Proceedings

\title{
Effect of Foliar Pre-Harvest Calcium Application on the Mineral and Phytochemical Composition of Olive Oils ${ }^{\dagger}$
}

\author{
Irene Gouvinhas 1,* and Ana Isabel Barros 1,2 \\ 1 Centre for the Research and Technology of Agro-Environmental and Biological Sciences (CITAB), \\ University of Trás-os-Montes and Alto Douro (UTAD), 5000-801 Vila Real, Portugal; abarros@utad.pt \\ 2 Department of Chemistry, School of Life Sciences and Environment, UTAD, Quinta de Prados, \\ 5001-801 Vila Real, Portugal \\ * Correspondence: igouvinhas@utad.pt; Tel.: +00351-966744891 \\ + Presented at the 1st International Electronic Conference on Food Science and Functional Foods, \\ 10-25 November 2020; Available online: https://foods_2020.sciforum.net/.
}

Citation: Gouvinhas, I.; Barros, A.I. Effect of Foliar Pre-Harvest Calcium Application on the Mineral and Phytochemical Composition of Olive Oils. Proceedings 2021, 70, 66. https://10.3390/foods_2020-07662

Published: 9 November 2020

Publisher's Note: MDPI stays neutral with regard to jurisdictional claims in published maps and institutional affiliations.

Copyright: $\odot 2020$ by the authors. Licensee MDPI, Basel, Switzerland. This article is an open access article distributed under the terms and conditions of the Creative Commons Attribution (CC BY) license (http://creativecommons.org/licenses/by/4.0/).

\begin{abstract}
Background: Several studies have investigated the possibility of using nutrients supplied as fertilizers to improve yield, firmness or final olive fruit size, however, scarce are the studies about the effect of pre-harvest foliar calcium application rate on mineral, quality and phytochemical composition of olive oils, which is the main goal of this investigation. Methods: For this study, an organic calcium compound (at two rates: $20 \mathrm{~g} /$ tree and $40 \mathrm{~g} /$ tree) and control (water) were applied to olive trees of three different cultivars (Cobrançosa, Galega, and Picual) at three different moments in a certified olive orchard in Portugal. At the commercial maturity, the olive fruits were harvested and processed to obtain the monovarietal olive oils. Results: The calcium application did not reveal significant changes on the quality parameters of the monovarietal olive oils, remaining extra virgin olive oils, however, the analysis of Ca mineral content revealed a significant increase of this content for some olive oil cultivars. Furthermore, some phenolic compounds concentration of olive oils were improved with the Ca foliar application, in opposite of antioxidant activity that was negatively affected. Conclusions: This investigation comes to demonstrate the cultivar effect on the final phytochemical composition, as well as the effect that Ca mineral content effect on the biosynthesis of bioactive compounds.
\end{abstract}

Keywords: foliar application; calcium; olive oils; mineral composition; phenolic content; antioxidant activity

\section{Introduction}

Calcium $(\mathrm{Ca})$ is one of the major essential nutrients of the plants, playing important roles on the fruit growth and development, as well as in the quality and firmness maintenance of several fruits and crops as a constituent of cell walls and membranes, providing protection and resistance against pests and diseases [1,2]. The lack of this nutrient in crop plants can cause the decline of their quality and yield, as well as of the shelf life of the corresponding fruits [1]. In humans, the deficiencies in Ca can origin important health disorders, such as hypertension, osteoporosis, and colorectal cancer, which can also cause economic costs [3].

Several studies have shown the effect of the application of Ca on the quality, yield and growth of some fruits, such as strawberry, tomato, and blueberry [4-6]. However, the literature on the high importance of calcium olive nutrition is very scarce, whereby, in this work we intend to study the effect of the pre-harvest foliar application of Ca on the mineral, quality and phytochemical parameters of different monovarietal olive oils during two consecutive harvest years. 


\section{Material and Methods}

\section{Plant Material and Treatments}

The present work was carried on olive trees, from three different cultivars ('Galega Vulgar', 'Cobrançosa', and 'Picual'), on a certified olive grove, at the National Institute for Agricultural and Veterinary Research (INIAV) located in Elvas, Portugal (38 $54^{\circ} 53.35^{\prime \prime} \mathrm{N}$ and 7¹9'11.06" O) during the crop seasons 2018 and 2019.

The experimental design included three treatments, Ca fertilization (at two rates: 20 $\mathrm{g} /$ tree and $40 \mathrm{~g} /$ tree) and control (with water application), and three replicates with three different trees of comparable age and vigour, evenly spaced between them, within the same growing area, totalizing 9 trees per treatment and 27 marked trees in the total experiment. Calcium rich elemental fertilizer was applied for the first time during both growing seasons at three moments (in August, September, and October), which composition consists in $\mathrm{CaO}(34 \% \mathrm{p} / \mathrm{p}), \mathrm{B}(0.8 \% \mathrm{p} / \mathrm{p})$, and $\mathrm{Zn}(1.72 \%, \mathrm{p} / \mathrm{p})$, at a rate of $20 \mathrm{~g} \mathrm{Ca} /$ tree and $40 \mathrm{~g}$ $\mathrm{Ca} /$ tree. Regarding the control samples, corresponding trees $(\mathrm{n}=9)$ were used without $\mathrm{Ca}$ treatment. At the commercial maturity, the olive fruits were harvested, being immediately transported to the laboratory mill where they were processed within $24 \mathrm{~h}$ to obtain the monovarietal olive oils. For the production of each olive oil, three kilos of fresh olive fruits were used using an Abencor system (Comercial Abengoa S.A., Sevilla, Spain) (INIAV I.P., Elvas, Portugal), simulating the commercial oil extraction. In this system, olives were crushed with an Abencor hammer mill and the past was mixed (at $25^{\circ} \mathrm{C}$ for $30 \mathrm{~min}$ ) and centrifuged using the Abencor system's malaxer and centrifuge, respectively, without addition of warm water. Afterwards, the oil was filtered and transferred into dark glass bottles without headspace, stored in the dark, at $4{ }^{\circ} \mathrm{C}$, until analysis.

The mineral, phytochemical composition and antioxidant capacity of olive oils have been performed.

\section{Results and Discussion}

\subsection{Ca Quantification}

The Ca concentration present in the monovarietal olive oils produced after the calcium field application was determined by Flame Atomic Absorption Spectrometry (Table 1). Taking into account the results obtained, it was observed that samples from cultivar Cobrançosa of both years showed an increase in the calcium content, between the control sample and the fortified samples, however, with no significant differences.

The opposite was found regarding Galega cultivar, with a significant increase from the control sample to the sample fortified with $20 \mathrm{~g} \mathrm{Ca}$ /tree (from $1.20 \pm 0.14$ and $1.18 \pm$ $0.09 \mathrm{~g} \mathrm{Kg}^{-1}$ to $1.83 \pm 0.12$ and $1.77 \pm 0.09 \mathrm{~g} \mathrm{Kg}^{-1}$, in 2018 and 2019 , respectively), remaining without significant differences when exposed to $40 \mathrm{~g} \mathrm{Ca} /$ tree. Regarding the cultivar Picual, there was a significant decrease in the calcium content from the control sample (1.49 \pm 0.00 and $1.25 \pm 0.01 \mathrm{~g} \mathrm{Kg}^{-1}$, in 2018 and 2019 , respectively) to the sample fortified with 20 $\mathrm{g} \mathrm{Ca}$ /tree $\left(0.92 \pm 0.15\right.$ and $1.01 \pm 0.01 \mathrm{~g} \mathrm{Kg}^{-1}$, in 2018 and 2019, respectively), followed by a significant increase for the sample with $40 \mathrm{~g} \mathrm{Ca}$ /tree application in 2019.

Therefore, through the analysis of the results obtained, it was concluded that the field application of calcium translates into a more significant increase in the calcium content in the oils produced when applied in a concentration of $20 \mathrm{~g} \mathrm{Ca} /$ tree, with the exception of Picual cultivar, probably due to cultivar factor, since different cultivars may react differently to this application. As previously mentioned, the calcium application effect depends on several factors, such as, the species of the plant under study, environmental conditions, soil types and fruit development [7]. For instance, in a previous study performed by Gouvinhas et al. (2016), the calcium concentration of olive oils was also analyzed at different stages of maturation of the cultivars Cobrançosa, Galega and Picual in the same field trial [8]. The concentration obtained for all the cultivars was $0.02 \mathrm{~g} \mathrm{Kg}^{-1}$, being much lower than those obtained in the present study, which may indicate the influence of the agro-environmental conditions of each year in the mineral content of olive oils. 
As previously referred, no studies refer the determination of the mineral content after their respective application in field. This could be of great value, once the final products can be enriched by the nutrient fertilizer applied, giving value-added products to consumers, with great nutritional potential.

Table 1. Calcium concentration of olive oils from three cultivars produced after a foliar calcium application at two rates $(20 \mathrm{~g} \mathrm{Ca} /$ tree and $40 \mathrm{~g} \mathrm{Ca} /$ tree $)$, including the control samples (water application).

\begin{tabular}{|c|c|c|c|}
\hline \multirow{2}{*}{\multicolumn{2}{|c|}{ Samples }} & \multicolumn{2}{|c|}{ Calcium $\left(\mathrm{g} \mathrm{Kg}^{-1}\right)$} \\
\hline & & \multirow{2}{*}{$\frac{\mathbf{2 0 1 8}}{\times 1.25 \pm 0.02 \mathrm{ab}}$} & \multirow{2}{*}{$\frac{2019}{1.12 \pm 0.02 b}$} \\
\hline \multirow{3}{*}{ Cobrançosa } & Control & & \\
\hline & $20 \mathrm{~g} \mathrm{Ca} /$ tree & $1.48 \pm 0.13 \mathrm{bc}$ & $1.51 \pm 0.10 \mathrm{bc}$ \\
\hline & $40 \mathrm{~g} \mathrm{Ca} /$ tree & $1.36 \pm 0.02 \mathrm{abc}$ & $1.45 \pm 0.08 \mathrm{bc}$ \\
\hline \multirow{3}{*}{ Galega } & Control & $1.20 \pm 0.14 \mathrm{ab}$ & $1.18 \pm 0.09 \mathrm{bc}$ \\
\hline & $20 \mathrm{~g} \mathrm{Ca} /$ tree & $1.83 \pm 0.12^{c}$ & $1.77 \pm 0.09 \mathrm{~d}$ \\
\hline & $40 \mathrm{~g} \mathrm{Ca} /$ tree & $1.58 \pm 0.25 \mathrm{bc}$ & $1.71 \pm 0.12 \mathrm{~d}$ \\
\hline \multirow{3}{*}{ Picual } & Control & $1.49 \pm 0.00 \mathrm{bc}$ & $1.25 \pm 0.01 \mathrm{bc}$ \\
\hline & $20 \mathrm{~g} \mathrm{Ca} /$ tree & $0.92 \pm 0.15^{a}$ & $1.01 \pm 0.01 \mathrm{a}$ \\
\hline & $40 \mathrm{~g} \mathrm{Ca}$ /tree & $1.13 \pm 0.01 \mathrm{ab}$ & $1.22 \pm 0.01 \mathrm{bc}$ \\
\hline p-value & & $Y * *$ & ** \\
\hline
\end{tabular}

$\bar{x}$ The values are presented as mean \pm standard deviation $(n=3)$. Different letters indicate significantly different results (Tukey's test, $p<0.05) .{ }^{\text {Y }}$ Significance: non-significant, N.S. $(p>0.05) ;{ }^{* *}$ significant at $p<0.01$.

\subsection{Qualitative and Quantitative Polyphenolic Determination}

The chromatographic determination of phenolic compounds present in these monovarietal olive oil samples produced after the pre-harvest foliar application of calcium is shown. Table 2 presents the phenolic compounds identified. As it can be observed, for the Cobrançosa samples, a significant increase of the concentration of hydroxytyrosol, tyrosol, oleuropein and luteolin was reached for both years of study between the control samples $\left(6.87 \pm 0.58,3.03 \pm 0.80,1.91 \pm 0.22\right.$, and $0.28 \pm 0.08 \mathrm{mg} \mathrm{g}^{-1}$ in 2018 respectively, and $9.83 \pm$ $0.65,2.04 \pm 0.50,2.35 \pm 0.21$, and $0.79 \pm 0.12$ in 2019, respectively) and those obtained after a Ca application of $20 \mathrm{~g} /$ tree $\left(8.89 \pm 1.99,6.49 \pm 1.32,3.43 \pm 0.74\right.$, and $1.73 \pm 0.30 \mathrm{mg} \mathrm{g}^{-1}$ in 2018 , respectively, and $12.38 \pm 1.04,7.71 \pm 0.31,3.99 \pm 0.30$, and $1.46 \pm 0.09 \mathrm{mg} \mathrm{g}^{-1}$ in 2019 , respectively), followed by a significant decrease of their concentrations after a Ca application of $40 \mathrm{~g} /$ tree, reaching similar values of the control samples. This behaviour didn't occur with Picual olive oil samples which demonstrated a decrease of the individual phenolic compounds with foliar Ca application, being significant for oleuropein at the both rate concentrations and harvest seasons, for tyrosol in 2019 at the both rate concentrations, and for luteolin after an application of $40 \mathrm{~g} \mathrm{Ca}$ /tree for both years. Regarding Galega cultivar olive oil samples, and as it happened with some other parameters studied, no significant differences was found between the control and the samples subjected to a Ca application at the olive grove, despite some variations demonstrated, with the exception of the luteolin compound which concentration significantly increase in 2018 after an application of $20 \mathrm{~g} \mathrm{Ca} /$ tree. 
Table 2. Phenolic profile of olive oils from three cultivars produced after a foliar calcium application at two rates (20 g Ca/tree and $40 \mathrm{~g}$ Ca/tree), including the control.

\begin{tabular}{|c|c|c|c|c|c|c|c|c|c|}
\hline \multicolumn{2}{|c|}{ Identification } & \multicolumn{2}{|c|}{$\begin{array}{c}\text { Hydroxytyrosol } \\
\left(m g g^{-1}\right)\end{array}$} & \multicolumn{2}{|c|}{$\begin{array}{l}\text { Tyrosol } \\
\left(m g g^{-1}\right)\end{array}$} & \multicolumn{2}{|c|}{$\begin{array}{l}\text { Oleuropein } \\
\left(m g g^{-1}\right)\end{array}$} & \multicolumn{2}{|c|}{$\begin{array}{c}\text { Luteolin } \\
\left(m g g^{-1}\right)\end{array}$} \\
\hline \multicolumn{2}{|c|}{ RT (min) } & \multicolumn{2}{|c|}{9.99} & \multicolumn{2}{|c|}{17.12} & \multicolumn{2}{|c|}{28.38} & \multicolumn{2}{|c|}{32.45} \\
\hline & & 2018 & 2019 & 2018 & 2019 & 2018 & 2019 & 2018 & 2019 \\
\hline \multirow{3}{*}{ Cobrançosa } & Control & $\times 6.87 \pm 0.58 \mathrm{~cd}$ & $9.83 \pm 0.65^{b}$ & $3.03 \pm 0.80^{c}$ & $2.04 \pm 0.50 \mathrm{bc}$ & $1.91 \pm 0.22 \mathrm{ab}$ & $2.35 \pm 0.21 b$ & $0.28 \pm 0.08 \mathrm{ab}$ & $0.79 \pm 0.12 \mathrm{bc}$ \\
\hline & $\begin{array}{c}20 \mathrm{~g} \\
\mathrm{Ca} / \text { tree }\end{array}$ & $8.89 \pm 1.99 \mathrm{~d}$ & $12.38 \pm 1.04^{c}$ & $6.49 \pm 1.32 \mathrm{~d}$ & $7.71 \pm 0.31 \mathrm{e}$ & $3.43 \pm 0.74^{c}$ & $3.99 \pm 0.30^{d}$ & $1.73 \pm 0.30^{c}$ & $1.46 \pm 0.09 \mathrm{de}$ \\
\hline & $\begin{array}{c}40 \mathrm{~g} \\
\mathrm{Ca} / \text { tree }\end{array}$ & $5.87 \pm 0.91 \mathrm{abc}$ & $9.03 \pm 0.35 \mathrm{~b}$ & $2.84 \pm 0.15 \mathrm{bc}$ & $2.37 \pm 0.31 \mathrm{~cd}$ & $1.89 \pm 0.30 \mathrm{ab}$ & $3.06 \pm 0.06^{c}$ & $0.19 \pm 0.03 \mathrm{ab}$ & $0.55 \pm 0.29 a b c$ \\
\hline \multirow{3}{*}{ Galega } & Control & $3.41 \pm 0.13^{a}$ & $4.22 \pm 0.38^{a}$ & $1.74 \pm 0.14 \mathrm{abc}$ & $1.28 \pm 0.11 \mathrm{ab}$ & $0.79 \pm 0.07$ a & $1.05 \pm 0.06^{a}$ & $0.13 \pm 0.01^{a}$ & $0.10 \pm 0.01^{a}$ \\
\hline & $\begin{array}{c}20 \mathrm{~g} \\
\mathrm{Ca} / \text { tree }\end{array}$ & $3.60 \pm 0.77 \mathrm{ab}$ & $4.80 \pm 0.95 a$ & $0.77 \pm 0.19 a$ & $1.01 \pm 0.02 a^{a}$ & $0.64 \pm 0.00 \mathrm{a}$ & $0.75 \pm 0.07 a$ & $0.74 \pm 0.11^{b}$ & $0.61 \pm 0.09 a b c$ \\
\hline & $\begin{array}{c}40 \mathrm{~g} \\
\mathrm{Ca} / \text { tree }\end{array}$ & $3.67 \pm 0.15 \mathrm{ab}$ & $5.37 \pm 1.15^{a}$ & $1.74 \pm 0.01 \mathrm{abc}$ & $1.29 \pm 0.19 \mathrm{ab}$ & $1.41 \pm 0.42 \mathrm{ab}$ & $1.17 \pm 0.05^{a}$ & $0.33 \pm 0.00 \mathrm{ab}$ & $0.35 \pm 0.09 a b$ \\
\hline \multirow{4}{*}{ Picual } & Control & $6.70 \pm 0.73 \mathrm{~cd}$ & $10.93 \pm 0.25 \mathrm{bc}$ & $2.95 \pm 0.12 b c$ & $3.08 \pm 0.04 \mathrm{~d}$ & $2.40 \pm 0.36 \mathrm{bc}$ & $2.43 \pm 0.13^{c}$ & $2.38 \pm 0.17 \mathrm{~d}$ & $2.26 \pm 0.25^{f}$ \\
\hline & $\begin{array}{c}20 \mathrm{~g} \\
\mathrm{Ca} / \text { tree }\end{array}$ & $4.38 \pm 0.47 \mathrm{abc}$ & $9.17 \pm 0.60 \mathrm{~b}$ & $1.08 \pm 0.04 \mathrm{ab}$ & $1.65 \pm 0.21 \mathrm{abc}$ & $1.05 \pm 0.49 \mathrm{a}$ & $0.93 \pm 0.13$ & $1.97 \pm 0.25 \mathrm{~cd}$ & $1.86 \pm 0.15$ ef \\
\hline & $\begin{array}{c}40 \mathrm{~g} \\
\mathrm{Ca} / \text { tree }\end{array}$ & $6.12 \pm 0.68 \mathrm{bc}$ & $9.47 \pm 0.49 \mathrm{~b}$ & $1.37 \pm 0.13 \mathrm{abc}$ & $1.85 \pm 0.07 \mathrm{abc}$ & $0.80 \pm 0.44^{a}$ & $1.00 \pm 0.11^{a}$ & $0.29 \pm 0.18 \mathrm{ab}$ & $0.92 \pm 0.06^{c d}$ \\
\hline & p-value & $\mathrm{Y***}$ & $* * *$ & $* * *$ & $* * *$ & $* *$ & $* * *$ & $* *$ & $* * *$ \\
\hline
\end{tabular}

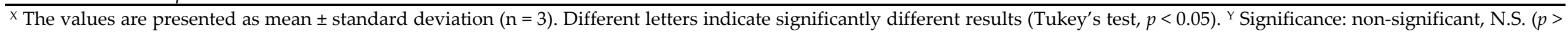
$0.05) ;{ }^{* *}$ significant at $p<0.01 ;{ }^{* * *}$ significant at $p<0.001$. RT - Retention Time. samples (water application). 
These differences found in the phenolic profile between cultivars showed the high impact factor that cultivars present on the phytochemical biosynthesis, meaning that this factor has to be always considered in the several investigations. Some authors investigated the foliar application of calcium in several fruits, such as apple, tomato, strawberry in their shelf life, disease combat, fruit size and firmness, free sugars, yield, soluble solids, and other physiological disorders, with positive results in most of these parameters [4,7,9-11].

However, no studies were found about the study of the effect of the foliar calcium application on the mineral, quality parameters and phytochemical content of olive oils from different cultivars, revealing the high importance of this investigation

\subsection{Antioxidant Activity}

The antioxidant activity of each olive oil under study was analyzed using the ABTS and DPPH methods, being the results presented in Figure 1. Contrary to expectations, since the antioxidant activity is correlated with the phenolic composition, the former method did not reveal any significant differences neither between cultivars nor between the different rates of $\mathrm{Ca}$ fertilization of each cultivar, with the exception of Galega samples which presented a significant increase with $20 \mathrm{~g} \mathrm{Ca}$ /tree in 2019. Regarding the DPPH method, a significant decrease of the antiradicalar activity was found for all the cultivars with the increase of the Ca concentration applied to the olive trees, being significant for Cobrançosa and Galega cultivars with an application of $40 \mathrm{~g} \mathrm{Ca} /$ tree in 2018 and 2019. Picual olive oils also presented a decrease of the antioxidant capacity after an application of $40 \mathrm{~g} \mathrm{Ca} /$ tree
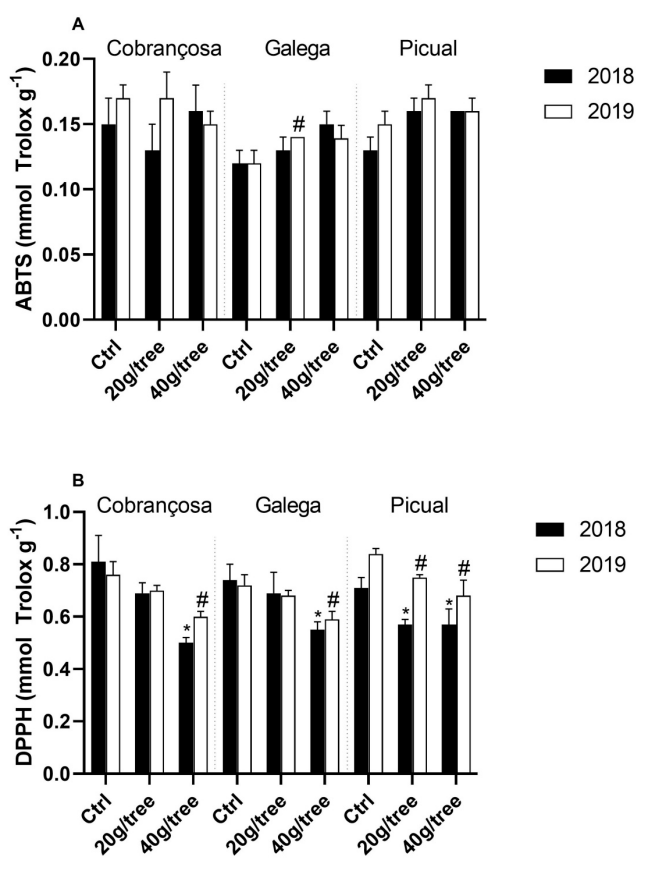

Figure 1. Antioxidant activity (A) ABTS method; (B) DPPH method) of olive oils from three cultivars produced after a foliar calcium application at two rates $(20 \mathrm{~g} \mathrm{Ca} /$ tree and $40 \mathrm{~g} \mathrm{Ca} /$ tree), including the control (Ctr) samples (water application). Statistically significant differences $(p<0.05)$ between the control and sample concentrations at respective cultivar for 2018 are denoted by * and for 2019 by \#.

In the experience described by Tekaya et al. (2013), the effect of the application of some fertilizers composed by different nutrients on the antioxidant activity and oil stability of olive oil as described. The analyzed results presented are in agreement with the results obtained in this work, since the oxidative stability significantly decreased with the application of a fertilizer composed by calcium [12]. 
In fact, the stability of the oil decreased significantly under the application of a fertilizer rich in $\mathrm{Ca}$ and $\mathrm{P}$, but increased with the application of more fertilizers combined with this one, as it happened with the phenolic contents. This corroborates the fact that the type of mineral and the different combination that can be done has influence in the phytochemical composition and antioxidant activity of olive oils, whereby it is possible to optimize olive oil composition and to obtain oils with higher beneficial phytochemicals and mineral content. However, it cannot be overlooked the cultivar factor which, as demonstrated in this work, can influence the content of these parameters. Furthermore, the capacity to chelate some metals make phenolic compounds, from natural sources, of great interest once they can scavenge free radicals, inhibit lipid peroxidation, and improve simultaneously the nutritional value of food products, reducing the use of synthetic compounds and possible problems caused by their consumption.

\section{Conclusions}

In this work, it was possible to understand the effect of calcium foliar application in olive trees on the phytochemical, mineral and quality parameters of the respective olive oils produced at two harvest seasons. This mineral application revealed to influence all these parameters, as well as the cultivar that demonstrated to affect the different results obtained.

Calcium is considered an important nutrient for plant height and development, but scarce are the studies regarding its influence on the secondary metabolism of plants. A rate application of $20 \mathrm{~g} \mathrm{Ca} /$ tree resulted in an increase of $\mathrm{Ca}$ and phenolic compounds of some olive oils cultivars, while $40 \mathrm{~g} \mathrm{Ca}$ /tree caused an increase of these parameters for other cultivars, highlighting the importance of controlling the nutrient concentration to be applied in the field.

Furthermore, some phenolic compounds and the antioxidant activity of some olive oils were negatively affected with the Ca foliar application, demonstrating not only the high influence of cultivar factor, but also the mineral effect on the oxidative enzymes activities.

Thereby, the supplementation of calcium or other nutrients in plants could be considered a good way to improve the quality and some phytochemical characteristics of the final products.

Author Contributions: Conceptualization, methodology, investigation, writing-original draft preparation, writing-review and editing, I.G. Conceptualization, supervision, funding acquisition, A.I.B. All authors have read and agreed to the published version of the manuscript.

Institutional Review Board Statement: Not applicable.

Informed Consent Statement: Not applicable.

Funding: This work was supported by National Funds by FCT - Portuguese Foundation for Science and Technology, under the project UIDB/04033/2020.

Conflicts of Interest: The authors declare no conflict of interest.

\section{References}

1. White, P.J.; Broadley, M.R. Calcium in Plants. Ann. Bot. 2003, 92, 487-511, doi:10.1093/aob/mcg164.

2. Kadir, S.A. Fruit Quality at Harvest of "Jonathan" Apple Treated with Foliarly-Applied Calcium Chloride. J. Plant Nutr. 2005, 27, 1991-2006, doi:10.1081/PLN-200030102.

3. Kin, C.F.W.; Shan, W.S.Y.; Shun, L.J.C.; Chung, L.P.; Jean, W. Experience of famine and bone health in post-menopausal women. Int. J. Epidemiol. 2007, 36, 1143-1150, doi:10.1093/ije/dym149.

4. Rab, A.; Haq, I. Foliar application of calcium chloride and borax influences plant growth, yield, and quality of tomato (Lycopersicon esculentum Mill.) fruit. Turk. J. Agric. For. 2012, 36, 695-701, doi:10.3906/tar-1112-7.

5. Angeletti, P.; Castagnasso, H.; Miceli, E.; Terminiello, L.; Concellón, A.; Chaves, A.; Vicente, A.R. Postharvest Biology and Technology Effect of preharvest calcium applications on postharvest quality, softening and cell wall degradation of two blueberry (Vaccinium corymbosum) varieties. Postharvest Biol. Technol. 2010, 58, 98-103, doi:10.1016/j.postharvbio.2010.05.015. 
6. Singh, R.; Sharma, R.R.; Tyagi, S.K. Pre-harvest foliar application of calcium and boron influences physiological disorders, fruit yield and quality of strawberry (Fragaria×ananassa Duch.). Sci. Hortic. (Amsterdam) 2007, 112, 215-220, doi:10.1016/j.scienta.2006.12.019.

7. Conway, W.S.; Sams, C.E.; Kelman, A. Enhancing the Natural Resistance of Plant Tissues to Postharvest Diseases through Calcium Applications. HortScience 1990, 29, 751-754.

8. Gouvinhas, I.; Domínguez-Perles, R.; Machado, N.; Carvalho, T.; Matos, C.; Barros, A.I.R.N.A. Effect of Agro-Environmental Factors on the Mineral Content of Olive Oils: Categorization of the Three Major Portuguese Cultivars. J. Am. Oil Chem. Soc. 2016, 93, 813-822.

9. Chéour, F.; Willemot, C.; Arul, J.; Desjardins, Y.; Makhlouf, J.; Charest, P.M. Foliar Application of Calcium Chloride Delays Postharvest Ripening of Strawberry. J. Am. Soc. Hortic. Sci. 1990, 115, 789-792.

10. Bonomelli, C.; Ruiz, R. Effects of foliar and soil calcium application on yield and quality of table grape Cv. "Thompson seedless". J. Plant Nutr. 2010, 33, 299-314, doi:10.1080/01904160903470364.

11. Neilsen, G.; Neilsen, D.; Dong, S.; Toivonen, P.; Peryea, F. Application of $\mathrm{CaCl} 2$ sprays earlier in the season may reduce bitter pit incidence in "Braeburn" apple. HortScience 2005, 40, 1850-1853.

12. Tekaya, M.; Mechri, B.; Bchir, A.; Attia, F.; Cheheb, H.; Daassa, M.; Hammami, M. Enhancement of antioxidants in olive oil by foliar fertilization of olive Trees. JAOCS J. Am. Oil Chem. Soc. 2013, 90, 1377-1386, doi:10.1007/s11746-013-2286-0. 